\title{
lodothyronine deiodinases and the control of plasma and tissue thyroid hormone levels in hyperthyroid tilapia (Oreochromis niloticus)
}

\author{
S Van der Geyten ${ }^{1}$, N Byamungu ${ }^{1,2, \dagger}$, G E Reyns ${ }^{1}$, E R Kühn ${ }^{1}$ \\ and $\mathbf{V} \mathbf{M}$ Darras ${ }^{1}$ \\ ${ }^{1}$ Laboratory of Comparative Endocrinology, Zoological Institute, K U Leuven, Naamsestraat 61, B-3000 Leuven, Belgium \\ ${ }^{2}$ Faculty of Agricultural Sciences, Catholic University of Bukavu and Teachers College of Bukavu (ISP), BP 285-854, Bukavu, \\ République Démocratique du Congo \\ (Requests for offprints should be addressed to S Van der Geyten; Email: serge.vandergeyten@bio.kuleuven.ac.be) \\ † We dedicate this paper to the memory of Prof. N Byamungu
}

\begin{abstract}
Thyroid status is one of the most potent regulators of peripheral thyroid hormone metabolism in vertebrates. Despite this, the few papers that have been published concerning the role of thyroid hormones in the regulation of thyroid function in fish often offer conflicting data. We therefore set out to investigate the effects of tetraiodothyronine (thyroxine) $\left(\mathrm{T}_{4}\right)$ or tri-iodothyronine $\left(\mathrm{T}_{3}\right)$ supplementation (48 p.p.m.) via the food on plasma and tissue thyroid hormone levels as well as iodothyronine deiodinase (D) activities in the Nile tilapia (Oreochromis niloticus). $\mathrm{T}_{4}$ supplementation did not induce a hyperthyroid state and subsequently had no effects on the thyroid hormone parameters measured, with the liver as the sole notable exception. In $\mathrm{T}_{4}$-fed tilapias, the hepatic $\mathrm{T}_{4}$ levels increased substantially, and this was accompanied by an increase in in vitro type I deiodinase (D1) activity. Although the lack of effect of $\mathrm{T}_{4}$ supplementation could be partially explained by an inefficient uptake of $\mathrm{T}_{4}$ from the
\end{abstract}

gut, our current data suggest that also the increased conversion of $T_{4}$ into reverse $(r) T_{3}$ by the $D 1$ present in the liver plays an important role in this respect. In addition, $\mathrm{T}_{3}$ supplementation increased plasma $\mathrm{T}_{3}$ and decreased plasma $T_{4}$ concentrations. $T_{3}$ levels were also increased in the liver, brain, kidney, gill and white muscle, but without affecting local $\mathrm{T}_{4}$ concentrations. However, this increase in $\mathrm{T}_{3}$ availability remained without effect on D1 activity in liver and kidney. This observation, together with the 6-n-propylthiouracyl (PTU) insensitivity of the D1 enzyme in fish, sets the D1 in teleost fish clearly apart from its mammalian and avian counterparts. The changes in hepatic deiodinases confirm the role of the liver as an important $\mathrm{T}_{3}$-regulating tissue. However, the very short plasma half-life of exogenously administered $\mathrm{T}_{3}$ implies the existence of an efficient $\mathrm{T}_{3}$ clearing/degradation mechanism other than deiodination.

Journal of Endocrinology (2005) 184, 467-479

\section{Introduction}

In fish, as in other vertebrates, the thyroid secretes predominantly $3,5,3^{\prime}, 5^{\prime}$-tetraiodothyronine (thyroxine) $\left(\mathrm{T}_{4}\right)$, which has to be converted into $3,5,3^{\prime}$-tri-iodothyronine $\left(T_{3}\right)$ in order to bind to a nuclear receptor and exert its full biologic activity. This activation, as well a $s$ the inactivation of thyroid hormones, occurs not in the thyroid, but in the periphery through the action of iodothyronine deiodinases (Eales \& Brown 1993, Mol et al. 1997, 1998). Although it has long been an issue of debate, recent molecular studies have indicated that in fish, as in mammals, at least three different selenocysteinecontaining deiodinases exist, with similar properties to their mammalian counterparts. The type I deiodinase (D1), which is capable of both activation (outer-ring deiodination (ORD)) and inactivation (inner-ring deiodination (IRD)), is a high $K_{\mathrm{m}}\left(\mu \mathrm{M}\right.$ range for reverse $\left.(\mathrm{r}) \mathrm{T}_{3}\right)$, high $V_{\max }$ enzyme which is, in contrast to D1 in mammals and birds, insensitive to inhibition by $6-n$-propylthiouracyl (PTU) (Sanders et al. 1997, Orozco et al. 2003). However, the type II deiodinase (D2) is a low $K_{\mathrm{m}}$ (nM range for $\mathrm{T}_{4}$ ), low $V_{\max }$ enzyme that only has ORD activity and is also not inhibited by PTU (Valverde-R et al. 1997, Orozco et al. 2002). The type III deiodinase (D3), like D2, is also a selective, low $K_{\mathrm{m}}$ (nM range for $\mathrm{T}_{3}$ ), low $V_{\max }$ enzyme that is not inhibited by PTU, but, unlike D2, it is capable only of IRD (Sanders et al. 1999).

Although a large number of factors (endocrine and others) are known to affect peripheral thyroid hormone metabolism, thyroid status itself is one of the most potent regulators of iodothyronine deiodinase expression and 
activity (Bianco et al. 2002). Despite this, the literature records surprisingly few data on the role of thyroid hormones in the regulation of fish deiodination. Mol et al. (1999) reported that in the Nile tilapia, induction of hyperthyroidism by feeding the animals with $\mathrm{T}_{3}$ supplemented food (12 p.p.m.) for 11 days resulted in a prominent decrease in hepatic D2 activity, whereas hepatic D3 activity increased. However, neither brain nor gill D3 activity was affected, nor was kidney D1 activity. Similarly, in rainbow trout (Finnson \& Eales 1999) and sturgeon (Plohman et al. 2002), administration of $\mathrm{T}_{3}$ supplemented (12 p.p.m.) food also resulted in a decrease in in vitro hepatic D2 activity. However, only in rainbow trout was this also accompanied by a decrease in hepatic D3 activity, whereas liver D1 remained unaffected (Finnson \& Eales 1999). In addition, hyperthyroidism had no effect on D3 levels in the brain of sturgeon (Plohman et al. 2002) and Atlantic salmon (Morin et al. 1995), whereas in the gills of rainbow trout (MacLatchy \& Eales 1993) hyperthyroidism had no effect on D3 activity levels. The only case so far in which hyperthyroidism induced an increase in in vitro D3 activity, other than in the liver, was noted by Plate et al. (2002), who observed that in 1 -year-old rainbow trout that had been immersed for 6 weeks in 100 p.p.m. $\mathrm{T}_{4}$, liver and brain D3 activities were increased. However, so far, no data are available on the regulation of iodothyronine deiodinases in $\mathrm{T}_{4}$-fed hyperthyroid fish, making it difficult to come to any clear-cut conclusions. In addition, in most of these $\mathrm{T}_{3}$ supplementation studies, plasma $T_{3}$ concentrations were only slightly elevated, so that it is possible that intracellular $\mathrm{T}_{3}$ levels in the brain and the gills were not sufficiently high to affect D3 in these tissues. This would probably not be the case in the liver, since it directly receives the $\mathrm{T}_{3}$ absorbed by the intestine, thereby making it more prone to react to $T_{3}$ supplementation. On the other hand, the different effects of $\mathrm{T}_{3}$-induced hyperthyroidism on liver $\mathrm{D} 3$ versus brain and gill D3 might point to differences in D3 regulation between these tissues. In order to resolve this controversy, it is necessary to determine the intracellular thyroid hormone concentrations in these tissues during hyperthyroidism, and this, to our knowledge has never been done.

We therefore decided to study the effects of experimentally induced hyperthyroidism on plasma $\mathrm{T}_{3}$ and $\mathrm{T}_{4}$ levels, as well as $\mathrm{T}_{3}$ and $\mathrm{T}_{4}$ concentrations, in liver, kidney, brain, gill and white muscle of tilapia (Oreochromis niloticus). Also the in vitro activity of the different deiodinases expressed in liver, kidney, brain and gill was measured. Since previous studies in tilapia had demonstrated that the use of 12 p.p.m. $\mathrm{T}_{3}$-supplemented food resulted in only a modest increase in plasma $T_{3}$ levels (Mol et al. 1999), we decided to induce hyperthyroidism by feeding the fish food supplemented with 48 p.p.m. $\mathrm{T}_{3}$ or 48 p.p.m. $\mathrm{T}_{4}$ for 2 weeks. This was done to ensure that, in addition to the plasma thyroid hormone levels, the intracellular $\mathrm{T}_{3}$ and $\mathrm{T}_{4}$ levels would also increase significantly, thereby expanding the hyperthyroid state to the cellular level. For a better insight into the dynamics of thyroid hormone metabolism in fish, we also measured the same thyroid-related parameters during the 2 weeks following the treatment period, when thyroid-supplemented food was replaced with a control diet. In this respect, also the half-life of exogenously administered $\mathrm{T}_{3}$ was measured.

\section{Materials and Methods}

\section{Experimental design}

A total of 360 adult tilapia (O. niloticus) of both sexes were procured from a commercial fish farm (Maryn Donkers, Boerdonk, The Netherlands). Three weeks before the start of the experiment, the fish were divided into nine groups of 40 fish and were acclimatized in 601 tanks supplied with aerated tap water under a $12 \mathrm{~L}: 12 \mathrm{D}$ photoperiod and an average temperature of $27^{\circ} \mathrm{C}$. The average weight of the fish at the start of the experiment was $190 \cdot 4 \pm 2 \cdot 9 \mathrm{~g}$. Fish were fed four times a day $(0800,1200,1600$ and $2000 \mathrm{~h}$ ) to satiety with commercial tilapia pellets containing $49 \%$ crude protein, $11 \%$ crude fat and $1.5 \%$ cellulose, enriched with vitamin $A$, vitamin $\mathrm{D}_{3}$ and vitamin $\mathrm{E}$ (TI-3 tilapia start feed, Trouw Nutrition Belgium, Ghent, Belgium). Three groups of fish $(n=120)$ were made hyperthyroid by treatment with 48 p.p.m. $\mathrm{T}_{3}$ in the food during 14 days, while three other groups $(n=120)$ were given food containing 48 p.p.m. $\mathrm{T}_{4}$. For supplementation of the food, $\mathrm{T}_{3}$ and $\mathrm{T}_{4}$ were dissolved in ethanol and sprayed over the food with a Wurster-coater (Glatt, Binzen, Germany). Therefore, the remaining three groups, which served as controls, received food treated with an identical amount of ethanol. Treatment with the hormone-supplemented food was applied during the first 2 weeks of the experiment (days 1-15). Immediately after sampling at day 14, hormone-supplemented food was withdrawn, and all groups were fed the control diet for an additional 14 days (days 15-28). Just before the start of the experiment (day 0), blood and tissue samples were taken from 10 animals, while an additional 10 animals per treatment group were sampled on days 1-3, 7, 14-17, 21 and 28. To exclude variation due to circadian changes in hormone levels or deiodinase activities, all samples were taken between 1400 and $1600 \mathrm{~h}$. Blood was collected in heparinized tubes by puncture of the caudal vein within $1 \mathrm{~min}$ after netting. After centrifugation, plasma was collected and stored at $-20{ }^{\circ} \mathrm{C}$ until assayed for hormone levels. Fish were subsequently measured, weighed and killed by decapitation. Liver, brain, gill, kidney and white muscle were isolated, frozen in liquid nitrogen and stored at $-80^{\circ} \mathrm{C}$ when used to determine deiodinase activity or $-20{ }^{\circ} \mathrm{C}$ when used to measure thyroid hormone levels.

For determination of the plasma $\mathrm{T}_{3}$ half-life, eight fish from the batch used in the first experiment were housed in 
individual 601 glass tanks supplied with aerated tap water under a $12 \mathrm{~L}: 12 \mathrm{D}$ photoperiod and an average temperature of $27^{\circ} \mathrm{C}$. Before the start of the experiment $(0 \mathrm{~min})$, a $200 \mu \mathrm{l}$ blood sample was taken, as described before. Subsequently, the fish were injected intravenously with $200 \mu \mathrm{l} \mathrm{T} \mathrm{T}_{3}$ solution $(1 \mathrm{ng} / \mu \mathrm{l})$. Additional $200 \mu \mathrm{l}$ blood samples were collected 2, 5, 10, 20, 40, 60, 90, 120, 180 and $300 \mathrm{~min}$ after the injection. Plasma was stored at $-20{ }^{\circ} \mathrm{C}$ until assayed for $\mathrm{T}_{3}$.

The University Ethical Committee for Animal Experiments approved all experimental animal manipulations.

\section{Determination of $T_{4}$ and $T_{3}$ levels in plasma and tissues}

$\mathrm{T}_{3}$ and $\mathrm{T}_{4}$ levels in plasma and in liver, kidney, brain, gill and muscle extracts were measured by radioimmunoassay (RIA) as described previously (Van der Geyten et al. 2001). Tissues were extracted as described in detail elsewhere (Reyns et al. 2002). In short, $200 \mathrm{mg}$ tissue were homogenized in methanol, and 1500-2000 c.p.m. of outer-ring ${ }^{131} \mathrm{I}_{-} \mathrm{T}_{3}$ and ${ }^{125} \mathrm{I}-\mathrm{T}_{4}$ were added as internal recovery tracers. Thereafter, chloroform was added to form a solvent mixture of chloroform:methanol $(\mathrm{v} / \mathrm{v}=2: 1)$. After centrifugation $\left(15 \mathrm{~min}, 1900 \mathrm{~g}, 4^{\circ} \mathrm{C}\right.$ ), the pellet was re-extracted with the same solvent. Both supernatants were combined and further extracted with chloroform:methanol:water $(8: 4: 3)$ and $0.05 \% \mathrm{CaCl}_{2}$. The mixed solution was centrifuged $\left(10 \mathrm{~min}, 800 \mathrm{~g}, 4^{\circ} \mathrm{C}\right)$ to stimulate the separation of the apolar and the polar phases. The lower or apolar phase was re-extracted with pure upper layer, chloroform:methanol:water (3:49:48), in an amount equal to that removed. The obtained upper or polar layers were pooled and further purified by anion-exchange chromatography on AG 1-X2 resin columns (Bio-Rad). The columns were washed with solutions of decreasing pH. Finally, thyroid hormones were eluted with $70 \%$ acetic acid, evaporated to dryness and resuspended in RIA buffer $(0.05 \mathrm{M}$ sodium diethylbarbiturate, $0.05 \mathrm{M}$ sodium azide, $0.05 \mathrm{M}$ EDTA disodium salt dihydrate and 1\% bovine serum albumin). Recoveries of extracted thyroid hormones were usually $50-75 \%$ for ${ }^{131} \mathrm{I}_{-} \mathrm{T}_{3}$ and $40-60 \%$ for ${ }^{125} \mathrm{I}_{-} \mathrm{T}_{4}$. Plasma $\mathrm{T}_{3}$ and $\mathrm{T}_{4}$ levels were expressed as $\mathrm{pmol} / \mathrm{ml}$, whereas tissue thyroid hormone levels were expressed as $\mathrm{pmol} / \mathrm{g}$ wet tissue.

\section{Deiodinase assays}

Preparation of homogenates or microsomal fractions and measurement of D1, D2 and D3 activities were performed as described by Van der Geyten et al. (1998, 2001). For D1 activity, incubation mixtures contained 50000 c.p.m.

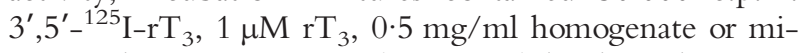
crosomal tissue protein, and $15 \mathrm{mM}$ dithiothreitol (DTT). For D2 activity, incubation mixtures contained 50000 c.p.m. $3^{\prime}, 5^{\prime}-{ }^{125} \mathrm{I}_{-} \mathrm{T}_{4}, 1 \mathrm{nM} \mathrm{T}, 0 \cdot 25-1 \mathrm{mg} / \mathrm{ml}$ homogenate or microsomal protein, and $30 \mathrm{mM} \mathrm{DTT}$. To detect possible interference from residual D1 activity, the ORD of $\mathrm{T}_{4}$ was also measured in the presence of $100 \mathrm{nM} \mathrm{T}_{4}$. At this substrate concentration, the $\mathrm{D} 2$ enzyme is saturated, so that all $\mathrm{I}^{-}$measured in the assay is derived from the ORD of $3^{\prime}, 5^{\prime}-{ }^{125} \mathrm{I}_{-} \mathrm{T}_{4}$ by $\mathrm{D} 1$. Only when $\mathrm{I}^{-}$production was minimal in the presence of $100 \mathrm{nM} \mathrm{T}_{4}$ was enzyme activity in the assay using $1 \mathrm{nM} \mathrm{T} \mathrm{T}_{4}$ considered to be true D2 activity. For D3 activity, incubation mixtures contained 150000 c.p.m. $3^{\prime}{ }^{125} \mathrm{I}_{-} \mathrm{T}_{3}, 1 \mathrm{nM} \mathrm{T}, 0 \cdot 5-1 \mathrm{mg} / \mathrm{ml}$ homogenate or microsomal tissue protein, and $30 \mathrm{mM}$ DTT. All deiodinase activities were calculated as the amount of substrate deiodinated per milligram of protein per minute.

\section{Statistical analysis}

Data were processed and analyzed by PRISM 4.02 software (Graphpad Software, San Diego, CA, USA), using two-way ANOVA followed by Bonferroni post-tests, in which data from the $\mathrm{T}_{3}$-fed and $\mathrm{T}_{4}$-fed groups were compared with the control group. Statistically significant differences are indicated as follows: ${ }^{*} P<0 \cdot 05,{ }^{*} P<0 \cdot 01$ and $* * * P<0 \cdot 001$. For determination of the plasma $\mathrm{T}_{3}$ half-life, a one-phase exponential decay curve $(\mathrm{Y}=\mathrm{a} \times$ $\exp (-\mathrm{K} \times \mathrm{X})+\mathrm{b})$ was fitted through the data, and the half-life was calculated as $t_{1 / 2}=0 \cdot 69 / \mathrm{K}$.

\section{Results}

Analysis of the data revealed what appeared to be sexrelated differences in the parameters studied, in the control group as well as in the thyroid hormone-treated groups. However, since only $15 \%$ of all animals in the studied cohort were female, these differences could not be verified statistically. Therefore, only the data from the male population (85\% of the samples) were taken into account and presented in the results.

\section{$T_{3}$ and $T_{4}$ levels in plasma and tissues}

For plasma thyroid hormone levels, as well as brain, muscle and gill $\mathrm{T}_{3}$ concentrations, significant changes were observed for treatment $(P<0 \cdot 01)$, time $(P<0 \cdot 05)$ and time $\times$ treatment interaction $(P<0 \cdot 05)$. For liver and kidney $\mathrm{T}_{3}$ levels, only treatment-related changes were observed $\left(P<0 \cdot 001\right.$ and $P<0 \cdot 01$ respectively). Except for liver $\mathrm{T}_{4}$ $(P<0 \cdot 001)$, no treatment-related changes were observed in tissue $\mathrm{T}_{4}$ levels. In contrast, significant changes in tissue $\mathrm{T}_{4}$ content were observed for time $(P<0.05)$ in all tissues examined, but not for the time $\times$ treatment interaction.

Plasma $T_{3}$ levels were elevated in the $T_{3}$-fed fish during week 1 of treatment, although this increase became significant only at day 3 (Fig. 1A). By day 14, circulating $\mathrm{T}_{3}$ concentrations had returned to control values. However, after withdrawal of the $\mathrm{T}_{3}$-supplemented food, 

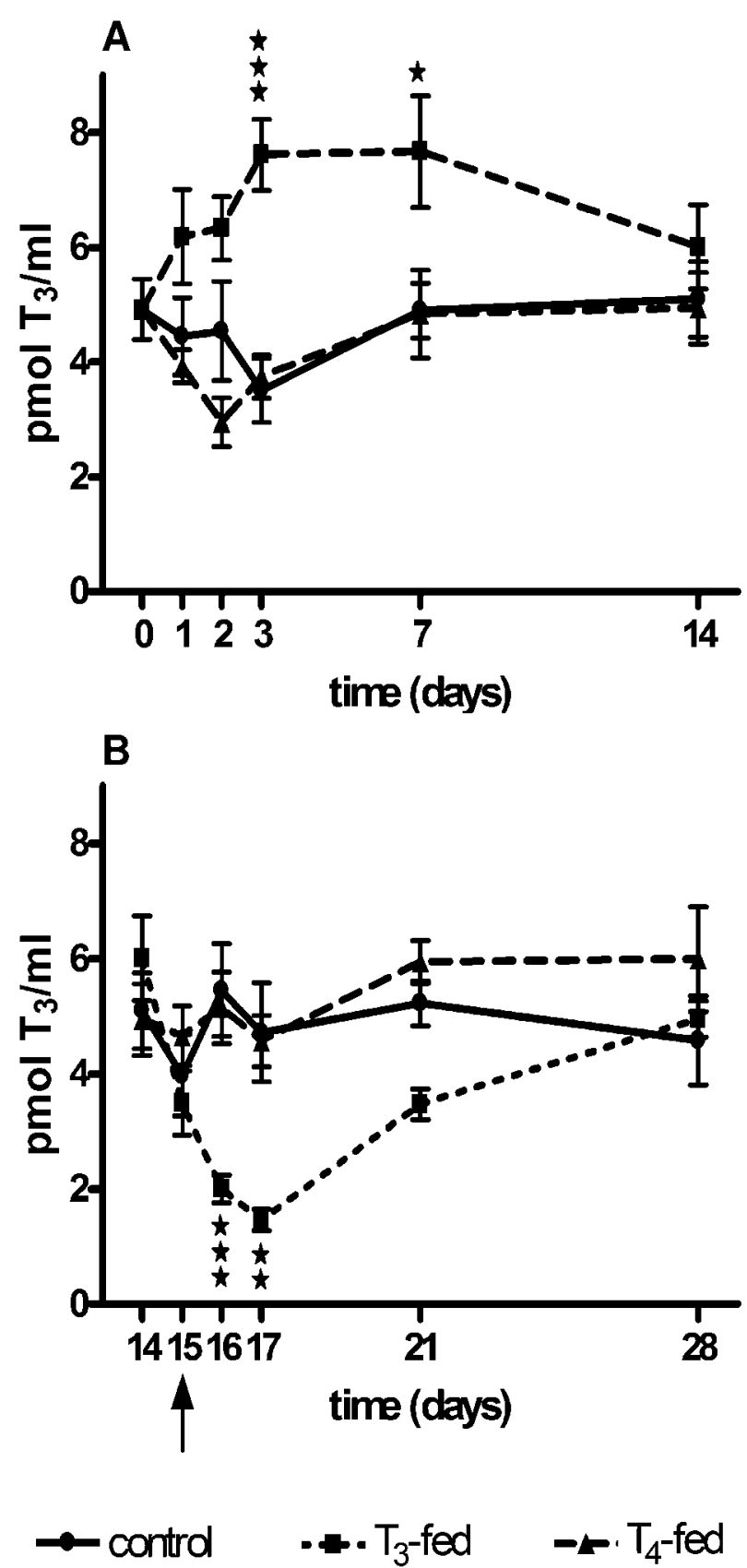

Figure 1 Plasma $T_{3}$ levels $(\mathrm{pmol} / \mathrm{ml})$ in control, $T_{3}$-fed and $T_{4}$-fed fish (A) during the treatment period (days 1-14) and (B) after changing to the control menu (days 15-28). Data are presented as the mean \pm S.E.M. $(n=10)$. The arrow $(\uparrow)$ indicates the first sampling after all groups had switched to the control diet. Statistically significant differences from the control group are indicated as follows: ${ }^{*} P<0 \cdot 05,{ }^{* *} P<0 \cdot 01$ and ${ }^{* * *} P<0 \cdot 001$ (black stars refer to the $\mathrm{T}_{3}$-fed group).

plasma $T_{3}$ levels rapidly fell, reaching a minimum 3 days later (day 17), after which they gradually returned to control values (Fig. 1B). $\mathrm{T}_{4}$ supplementation, in contrast, had no effect on plasma $T_{3}$ concentrations (Fig. 1). Plasma $\mathrm{T}_{4}$ levels were also not affected by feeding the $\mathrm{T}_{4}$ supplemented food, while $\mathrm{T}_{3}$ supplementation resulted in decreased plasma $T_{4}$ concentrations during the entire treatment period, although this was only statistically significant at day 14 (Fig. 2A). After we changed to the control diet, plasma $T_{4}$ in the $T_{3}$-fed fish returned to control levels within 1 day, whereas it tended to increase in the $\mathrm{T}_{4}$-fed groups, although this was only significant at day 21 (Fig. 2B).

Like plasma $T_{3}, T_{3}$ levels in the liver, kidney and brain were increased in the $\mathrm{T}_{3}$-fed groups. While in the liver (Fig. 3A) and brain (Fig. 5A) these levels remained above control levels during the entire first week of $T_{3}$ supplementation, this increase was short-lived in the kidney (Fig. 4A). After withdrawal of the $T_{3}$-supplemented food, $T_{3}$ levels in liver (Fig. 3B) and brain (Fig. 5B) fell below control levels during the first 3 days (until day 17), although this decrease was only significant in the brain. One week after the switch to the control diet (day 21), liver and brain $T_{3}$ concentrations had reached control values again. Neither liver, kidney, nor brain $\mathrm{T}_{3}$ concentrations were affected in the $\mathrm{T}_{4}$-fed groups (Figs $3-5$ ). $\mathrm{T}_{3}$ concentrations in muscle were, on average, higher in the $\mathrm{T}_{3}$-fed group than in the control group, although this was only significant at days 2 and 15 . As in liver and brain, withdrawal of the $\mathrm{T}_{3}$-supplemented food resulted in a transient decrease of muscle $\mathrm{T}_{3}$ levels, although this decrease never became statistically significant. $\mathrm{T}_{4}$ supplementation had no effect on thyroid hormone levels in muscle (Table 1). In the gills, $T_{3}$ supplementation induced higher $\mathrm{T}_{3}$ levels only at the end of the treatment period (day 14), while $T_{4}$ treatment remained without effect (Table 1). Tissue $\mathrm{T}_{4}$ concentrations in kidney, brain, muscle and gills remained largely unaffected by $\mathrm{T}_{3}$ and $\mathrm{T}_{4}$ supplementation, although they tended to be somewhat lower in the kidney of $\mathrm{T}_{3}$-fed fish (Table 1). Hepatic $\mathrm{T}_{4}$ levels also tended to be lower than control values in the $\mathrm{T}_{3}$-supplemented fish, but they were higher in the $\mathrm{T}_{4}$-fed fish (significant at day 7) (Table 1).

\section{Deiodinases in liver, kidney, brain and gill}

For hepatic D1, D2 and D3, as well as gill D3, significant changes were observed for treatment $(P<0 \cdot 01)$, time $(P<0 \cdot 001)$ and time $\times$ treatment interaction $(P<0 \cdot 001)$. Gill D2 showed significant changes only for time $(P<0 \cdot 01)$ and time $\times$ treatment interaction $(P<0 \cdot 05)$. Kidney D1 demonstrated only time-related changes $(P<0 \cdot 05)$, while kidney D3 and brain D3 were not affected by the experimental procedure.

$\mathrm{T}_{3}$ supplementation had no effect on in vitro $\mathrm{D} 1$ activity in the liver (Table 2). $\mathrm{T}_{4}$ supplementation, however, significantly increased hepatic D1 activity during week 1 of treatment (starting at day 3), whereas withdrawal of the $\mathrm{T}_{4}$-supplemented food resulted in a decrease of hepatic D1 

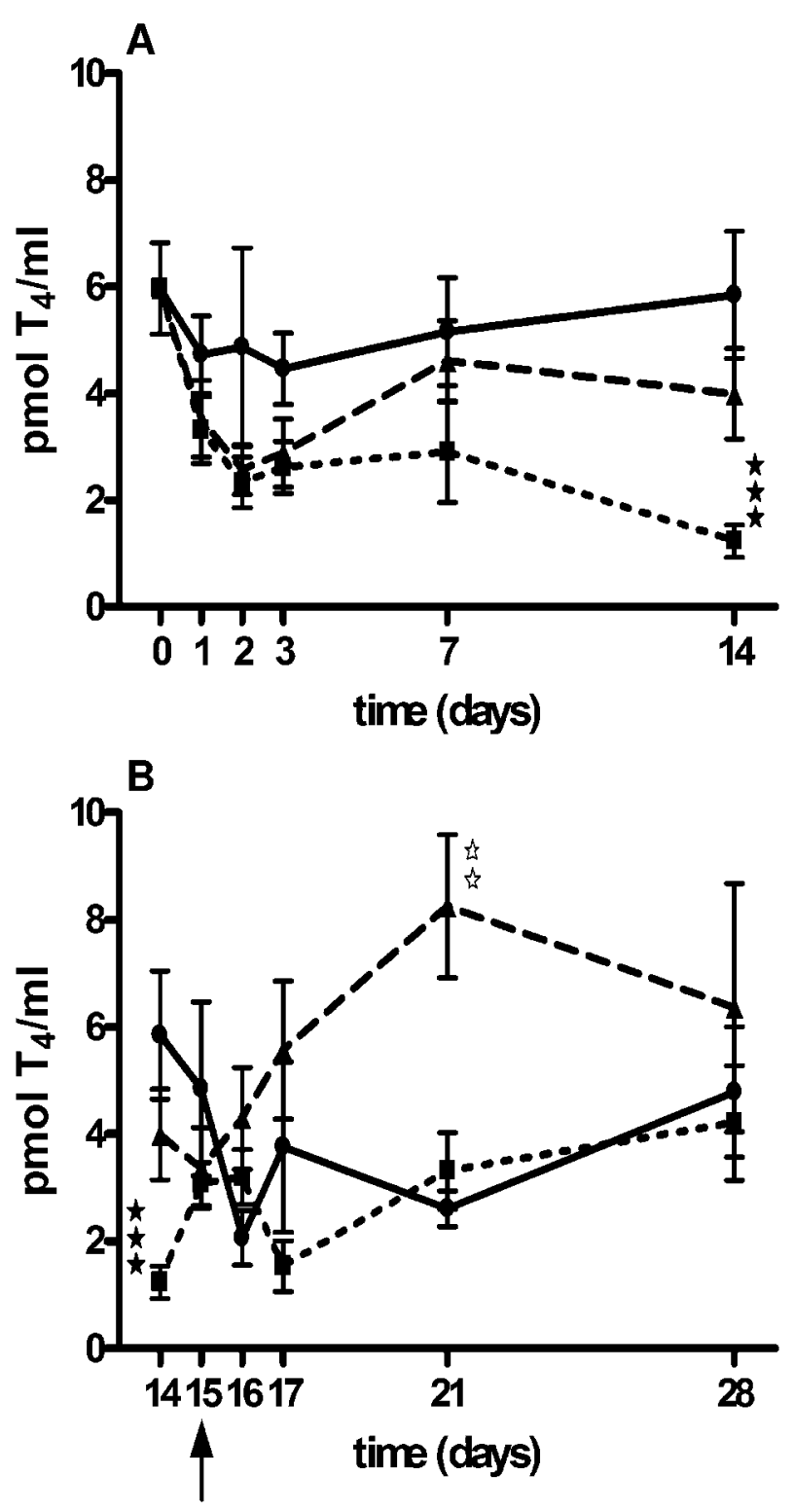

$\rightarrow$ contrd $\quad-\rightarrow \cdot T_{3}$-fed $\quad-2 \cdot T_{4}$-fed

Figure 2 Plasma $\mathrm{T}_{4}$ levels $(\mathrm{pmol} / \mathrm{ml})$ in control, $\mathrm{T}_{3}$-fed and $\mathrm{T}_{4}$-fed fish (A) during the treatment period (days 1-14) and (B) after changing to the control menu (days 15-28). Data are presented as the mean \pm S.E.M. $(n=10)$. The arrow $(\uparrow)$ indicates the first sampling after all groups had switched to the control diet. Statistically significant differences from the control group are indicated as follows: ${ }^{*} P<0 \cdot 05,{ }^{*} P<0 \cdot 01$ and ${ }^{*} * * P<0 \cdot 001$ (black stars refer to the $\mathrm{T}_{3}$-fed group; white stars to the $\mathrm{T}_{4}$-fed group).

activity that proved to be significant after 2 and 7 days (days 16 and 21) (Table 2). In contrast, in vitro hepatic D2 activity was significantly decreased in the $\mathrm{T}_{3}$-fed fish after 1 and 2 weeks of treatment (Fig. 6A), and withdrawal of

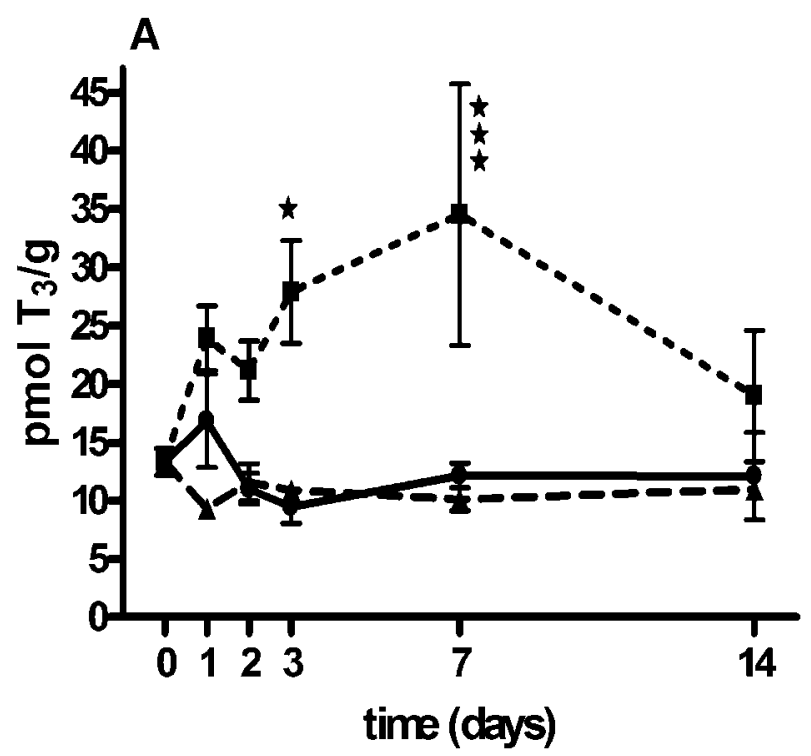

B

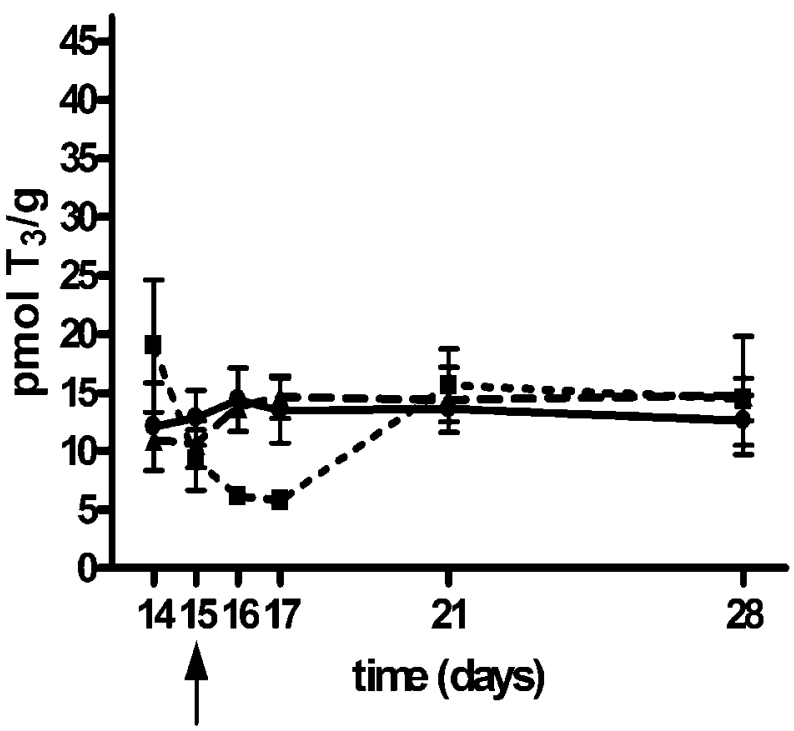

$\rightarrow$ contro $\quad-a \cdot T_{3}$-fed $\quad-r \cdot T_{4}$-fed

Figure 3 Liver $T_{3}$ levels (pmol/g) in control, $T_{3}$-fed and $T_{4}$-fed fish (A) during the treatment period (days 1-14) and (B) after changing to the control menu (days 15-28). Data are presented as the mean \pm S.E.M. $(n=5)$. The arrow $(\uparrow)$ indicates the first sampling after all groups had switched to the control diet. Statistically significant differences from the control group are indicated as follows: ${ }^{*} P<0 \cdot 05,{ }^{* *} P<0 \cdot 01$ and ${ }^{* * *} P<0 \cdot 001$ (black stars refer to the $T_{3}$-fed group).

the $\mathrm{T}_{3}$ - supplemented food resulted in a gradual return to control values that was complete after about 1 week (day 21) (Fig. 6B). $T_{4}$ supplementation, in turn, did not affect in vitro hepatic $\mathrm{D} 2$ activity (Fig. 6). Neither $\mathrm{T}_{3}$ nor $\mathrm{T}_{4}$ 

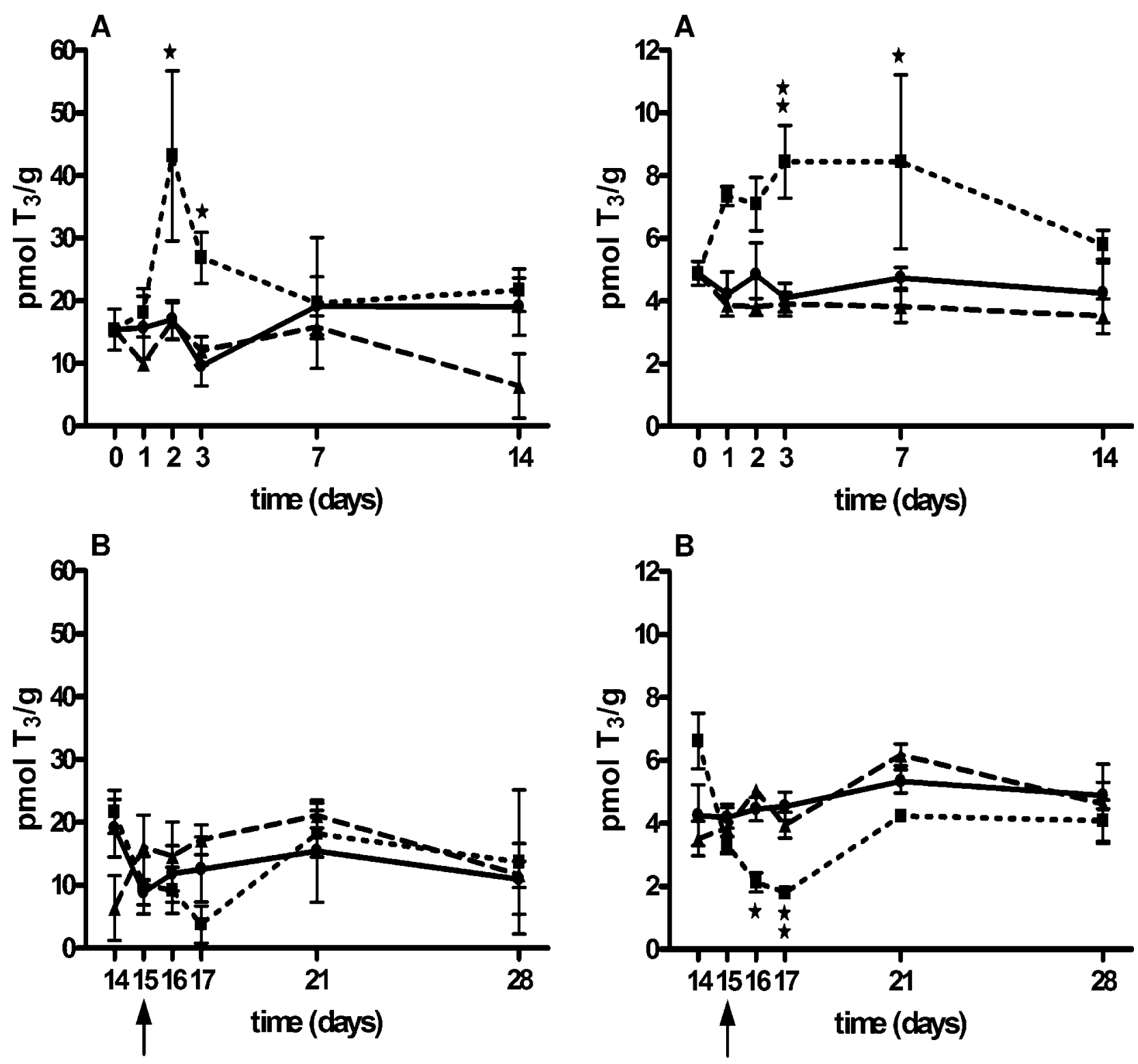

$\rightarrow$ contrd $\quad-\rightarrow \cdot T_{3}$-fed $\quad-r \cdot T_{4}$ fed

Figure 4 Kidney $\mathrm{T}_{3}$ levels (pmol/g) in control, $\mathrm{T}_{3}$-fed and $\mathrm{T}_{4}$-fed fish (A) during the treatment period (days 1-14) and (B) after changing to the control menu (days 15-28). Data are presented as the mean \pm S.E.M. $(n=5)$. The arrow $(\uparrow)$ indicates the first sampling after all groups had switched to the control diet. Statistically significant differences from the control group are indicated as follows: ${ }^{*} P<0 \cdot 05,{ }^{*} P<00.01$ and ${ }^{* * *} P<0 \cdot 001$ (black stars refer to the $\mathrm{T}_{3}$-fed group).

supplementation had any effect on in vitro renal D1 activity or on in vitro gill D2 activity (Table 2). Although D2 activity was also measured in kidney and brain, under the

experimental conditions described in this paper and with the kinetic assays used, no D2 activity could be detected in these tissues. 


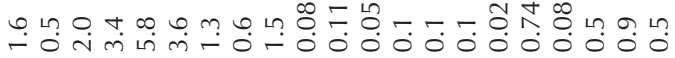
$H+H+H+H+H+H+H+H+H+H+H+H+H$

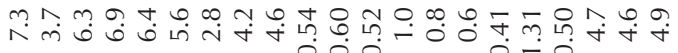

$\infty+\infty$ t $\mathrm{H}+\mathrm{H} H+\mathrm{H}+\mathrm{H}+\mathrm{H}+\mathrm{H}+\mathrm{H}+\mathrm{H}+\mathrm{H}+\mathrm{H}+\mathrm{H}+\mathrm{H}+\mathrm{H}$ H守原

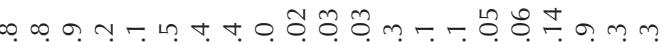

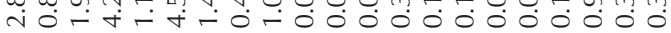
$H+H+H+H+H+H+H+H+H+H+H+H+H+H+H$

^|

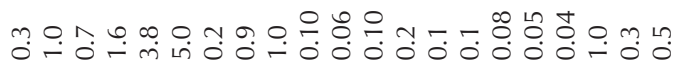

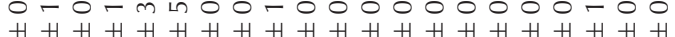

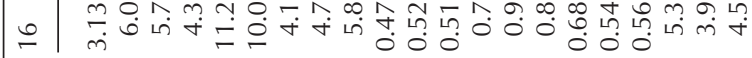
$\infty+\infty$ ก

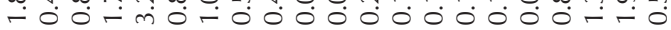
$H+H+H+H+H+H+H+H+H+H+H+H+H+H$

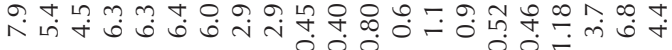

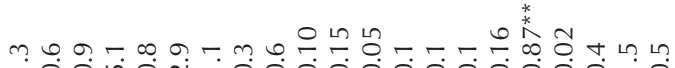
? $H+H+H+H+H+H+H+H+H+H+H+H+H+H$

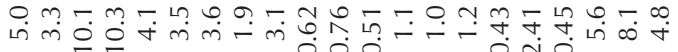

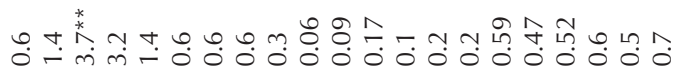

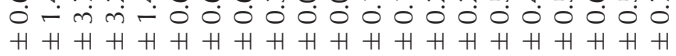
ம்

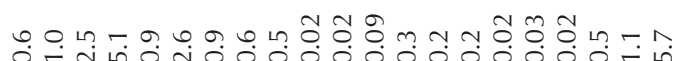
$H+H+H+H+H+H+H+H+H+H+H+H+H$ $\wedge$ ํ $\infty$.

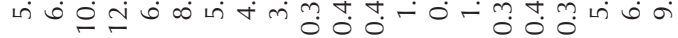

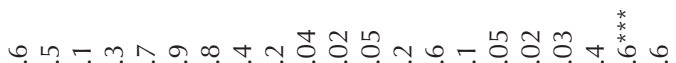
-1
0 $H+H+H+H+H+H+H+H+H+H+H+H+H+H$ б

n

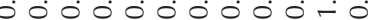
$H+H+H+H+H+H+H+H+H+H+H+H+H+H$

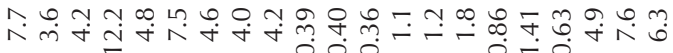

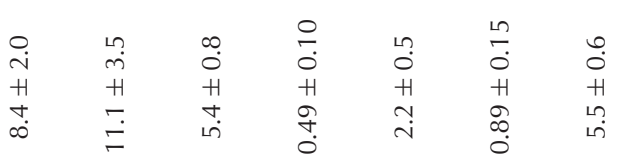

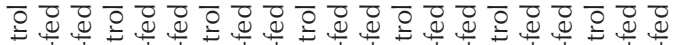

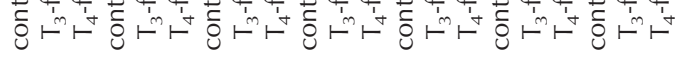

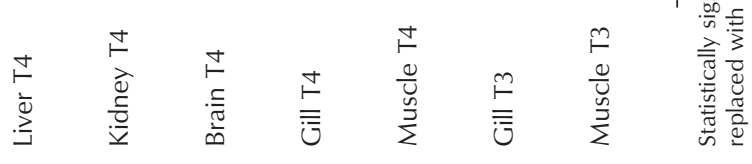



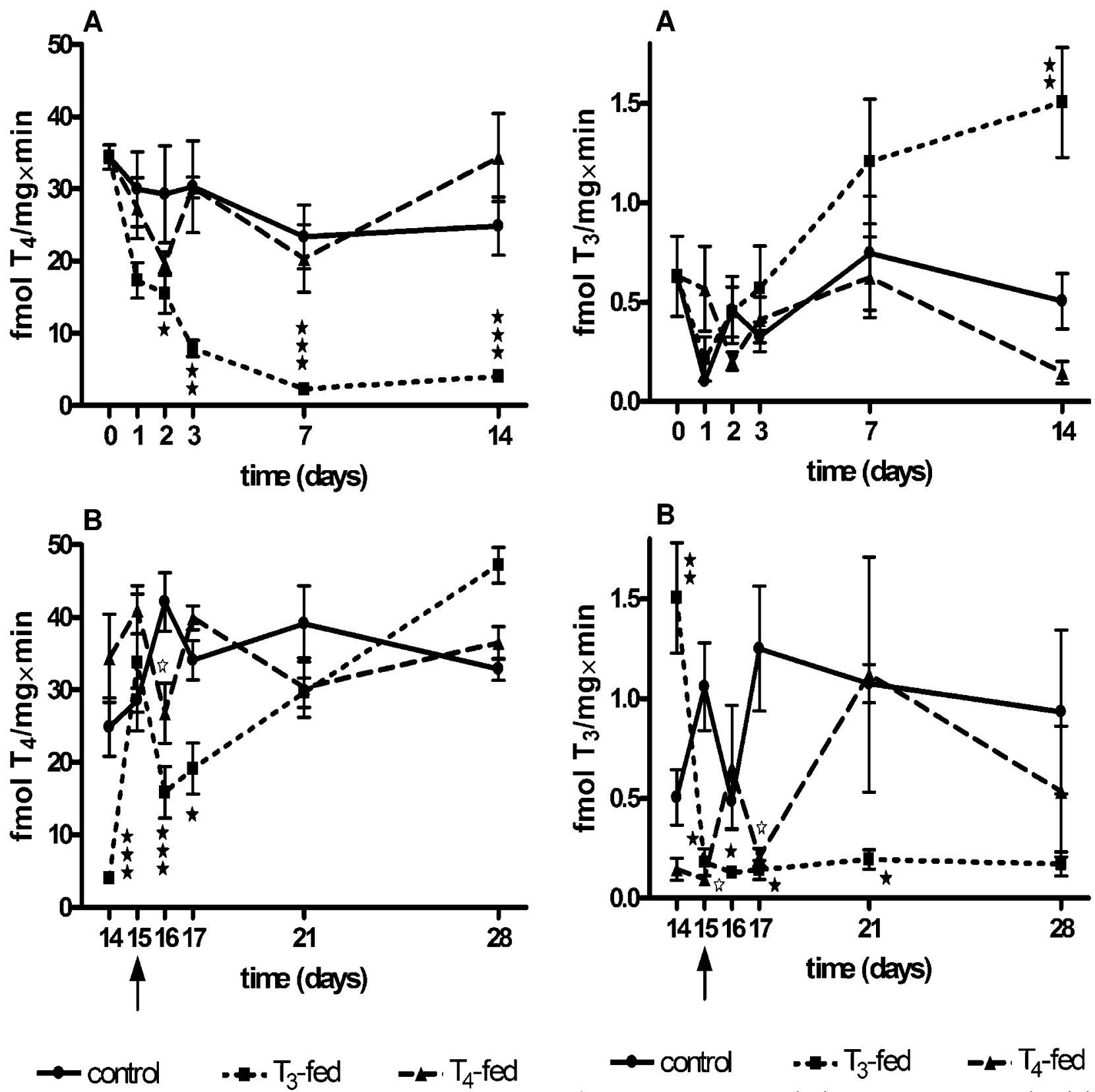

Figure 6 Liver D2 activities ( $\mathrm{fmol} \mathrm{T}_{4} / \mathrm{mg}$ per min) in control, $\mathrm{T}_{3}$-fed and $\mathrm{T}_{4}$-fed fish (A) during the treatment period (days 1-14) and (B) after changing to the control menu (days 15-28). Data are presented as the mean \pm S.E.M. $(n=5)$. The arrow $(\uparrow)$ indicates the first sampling after all groups had switched to the control diet. Statistically significant differences from the control group are indicated as follows: ${ }^{*} P<0 \cdot 05$, ${ }^{* *} P<0 \cdot 01$ and ${ }^{* * *} P<0 \cdot 001$ (black stars refer to the $T_{3}$-fed group; white stars to the $T_{4}$-fed group).

In contrast to hepatic D2, in vitro hepatic D3 activity increased significantly in the $\mathrm{T}_{3}$-fed fish by the end of the treatment period (Fig. 7A), and decreased rapidly the moment the $\mathrm{T}_{3}$-supplemented food was replaced with the control diet (Fig. 7B). These low levels were maintained until the end of the experiment. Overall, $\mathrm{T}_{4}$ supplementation had no effect on hepatic D3 activity, although activity levels were highly variable, especially after 

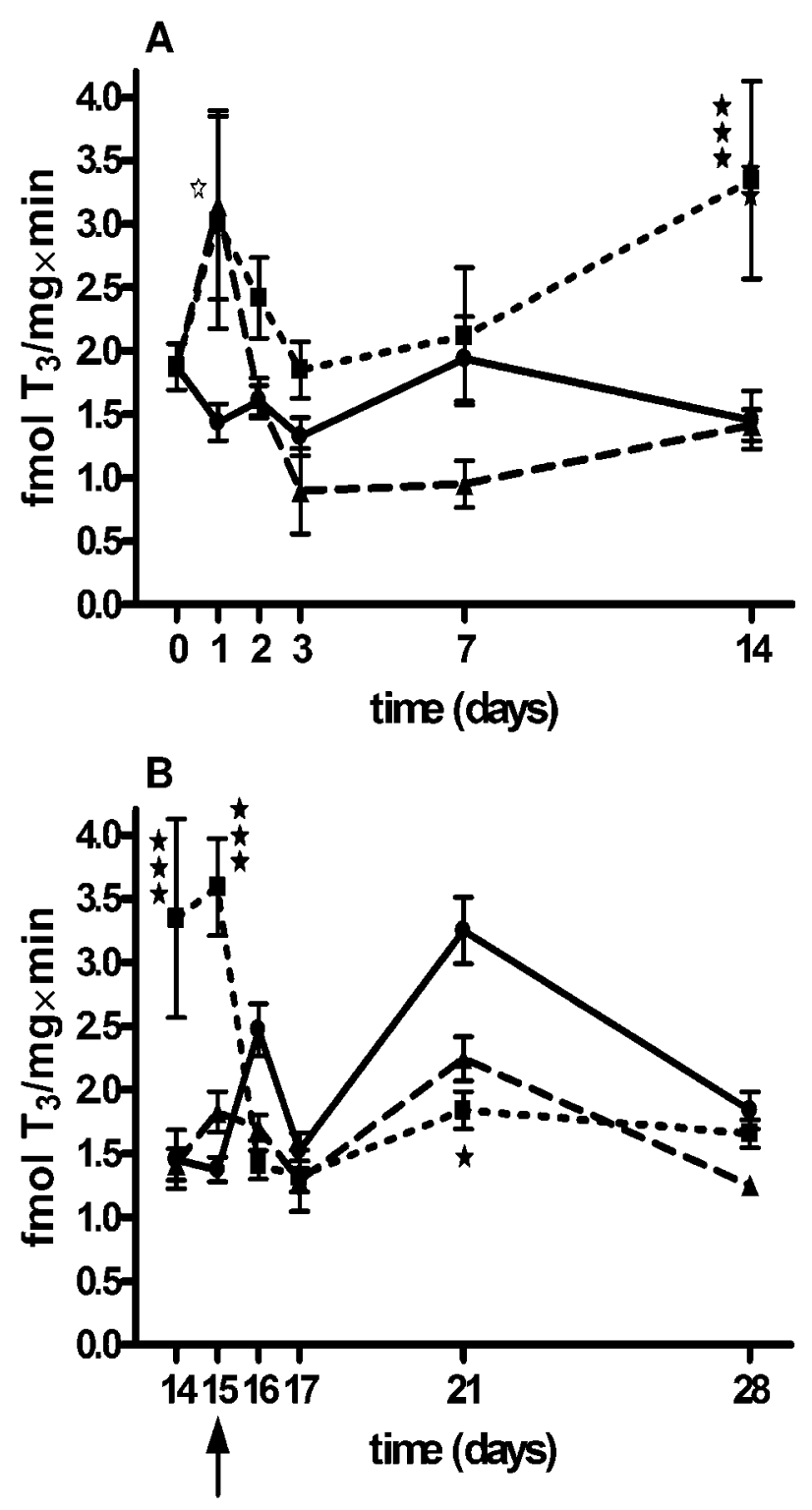

$\rightarrow$ control
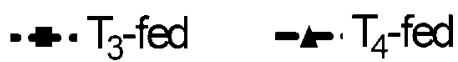

Figure 8 Gill D3 activities ( $\mathrm{fmol} \mathrm{T}_{3} / \mathrm{mg}$ per $\mathrm{min}$ ) in control, $\mathrm{T}_{3}$-fed and $\mathrm{T}_{4}$-fed fish (A) during the treatment period (days 1-14) and (B) after changing to the control menu (days 15-28). Data are presented as the mean \pm S.E.M. $(n=5)$. The arrow $(\uparrow)$ indicates the first sampling after all groups had switched to the control diet. Statistically significant differences from the control group are indicated as follows: ${ }^{*} P<0 \cdot 05,{ }^{* *} P<0.01$ and ${ }^{* *} * P<0 \cdot 001$ (black stars refer to the $T_{3}$-fed group; white stars to the $T_{4}$-fed group).

withdrawal of the $\mathrm{T}_{4}$-supplemented food (Fig. 7). As in the liver, gill in vitro $\mathrm{D} 3$ activity was higher after 2 weeks of treatment in the $\mathrm{T}_{3}$-fed fish (Fig. 8A). After the change to the control diet, gill D3 activity remained elevated for

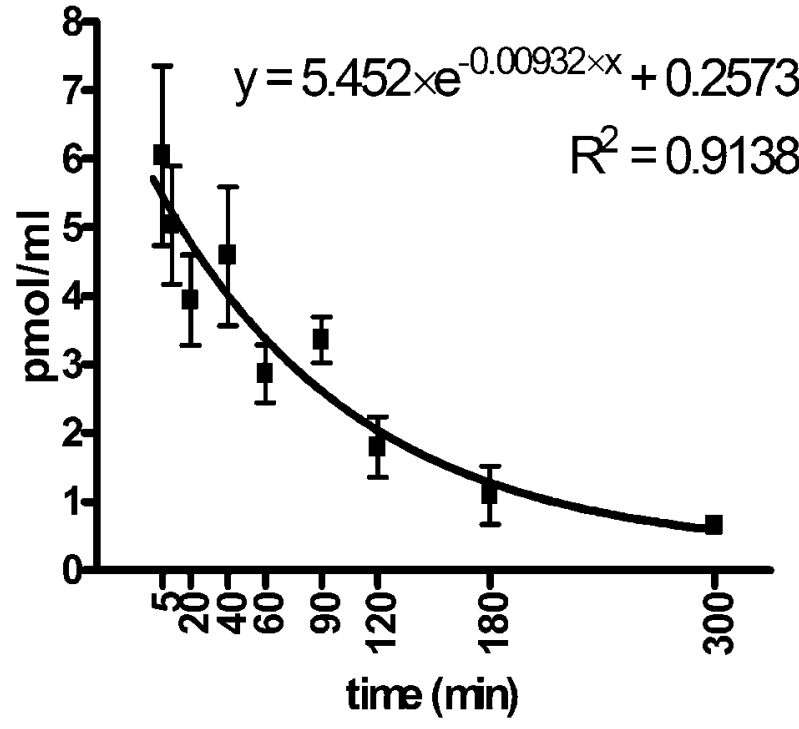

Figure $9 T_{3}$ clearance in plasma of fish after acute $T_{3}$ challenge. Data are presented as mean \pm S.E.M. $(n=8)$.

1 additional day (day 15), before falling below control levels until day 21 (Fig. 8B). $\mathrm{T}_{4}$ supplementation had no effects on gill D3 activity (Fig. 8). Thyroid hormone supplementation also had no effect on in vitro D3 activity in kidney and brain (Table 2) .

\section{Plasma $\mathrm{T}_{3}$ half-life}

The plasma half-life of exogenously administered $\mathrm{T}_{3}$ was determined to be $74 \cdot 37 \pm 4.37 \mathrm{~min}$ (Fig. 9).

\section{Discussion}

Two weeks of $\mathrm{T}_{4}$ supplementation (48 p.p.m.) had no effect on the plasma $T_{3}$ and $T_{4}$ concentrations in tilapia. These observations agree with data obtained in rainbow trout, where 3 days of $T_{4}$ supplementation (24 and 48 p.p.m.) also did not affect circulating thyroid hormone levels (Sweeting \& Eales 1992). In contrast, however, long-term immersion in $\mathrm{T}_{4}$-supplemented water $(6$ weeks, 100 p.p.m. $T_{4}$ ) has been shown to increase plasma $T_{3}$ and $\mathrm{T}_{4}$ levels significantly in rainbow trout (Plate et al. 2002). In addition to plasma $T_{3}$ and $T_{4}$, the tissue $T_{3}$ and $T_{4}$ concentrations, as well as the different deiodinases expressed in these tissues, also remained unaffected by feeding the $\mathrm{T}_{4}$-supplemented food, with the liver as the sole notable exception. In $\mathrm{T}_{4}$-fed tilapia, the hepatic $\mathrm{T}_{4}$ levels increased substantially, and this was accompanied by an increase in in vitro $\mathrm{D} 1$ activity, while hepatic $\mathrm{T}_{3}$ concentrations, as well as D2 and D3 activity, were not affected. This increase in intrahepatic $\mathrm{T}_{4}$ levels was also observed in killifish immersed for $12-24 \mathrm{~h}$ in $100 \mathrm{nM} \mathrm{T}$, 
although in this experiment hepatic $\mathrm{T}_{3}$ levels were also significantly increased, while D1 activity remained unaffected (García-G et al. 2004). The reason that $T_{4}$ supplementation via the food does not result in elevated plasma hormone levels is not readily apparent. Despite the difference in the amount of $\mathrm{T}_{4}$ used between the experimental approaches, the observation that immersion in $\mathrm{T}_{4^{-}}$ supplemented water increases both plasma and hepatic $\mathrm{T}_{3}$ and $\mathrm{T}_{4}$ levels, while feeding of $\mathrm{T}_{4}$-supplemented food does not, suggests that the $T_{4}$ ingested with the food is not taken up efficiently from the gut, as has been proposed by several authors (Collicutt \& Eales 1974, Higgs et al. 1979, Sweeting \& Eales 1992). Although this mechanism is probably involved, it does not explain why in the current experiment the increase in hepatic $T_{4}$ is not reflected at the plasma level. However, Byamungu et al. (1990) demonstrated that in tilapia stimulation of endogenous $T_{4}$ levels, as well as intravenous injection of $\mathrm{T}_{4}$, was each time accompanied by a 20 -fold increase in plasma $\mathrm{rT}_{3}$ concentrations. These results therefore suggest that the lack of effect of $\mathrm{T}_{4}$ supplementation via the food on circulating $\mathrm{T}_{3}$ and $\mathrm{T}_{4}$ might also be due to a rapid conversion of $\mathrm{T}_{4}$ into $\mathrm{rT}_{3}$. This hypothesis is supported by our finding that the increase in hepatic $T_{4}$ is accompanied by an increase in hepatic D1 activity, which in turn is able to increase the conversion of $\mathrm{T}_{4}$ into $\mathrm{rT}_{3}$ via IRD.

However, in accordance with previous data, administration of $\mathrm{T}_{3}$-supplemented food resulted in a significant increase in plasma $T_{3}$ levels (MacLatchy \& Eales 1993, Finnson \& Eales 1999, Mol et al. 1999), which in the present study was accompanied by a decrease in plasma $T_{4}$. Although this $\mathrm{T}_{4}$ decrease was not always observed earlier (Eales et al. 1990, Sweeting \& Eales 1992), more recent studies indicate that it is, as in other vertebrates, a logical consequence of the $\mathrm{T}_{3}$-induced negative feedback at the level of pituitary thyroid-stimulating hormone (TSH) production and release (Larsen et al. 1997, Moriyama et al. 1997, Mol et al. 1999). Our present study supports this conclusion, since, after withdrawal of the $\mathrm{T}_{3}$ supplemented food, when plasma $\mathrm{T}_{3}$ levels decreased and the negative feedback was abolished, plasma $T_{4}$ levels also returned to control values. In contrast, intracellular $\mathrm{T}_{4}$ concentrations in the tissues examined do not seem to be affected by the drop in circulating $\mathrm{T}_{4}$ levels, thereby providing further support for the negative feedback hypothesis. Besides plasma $T_{3}, T_{3}$ in the different tissues also increased substantially, thereby demonstrating that the ingested $\mathrm{T}_{3}$ reached all tissue compartments. In the gills, however, $\mathrm{T}_{3}$ concentrations are, on average, $80 \%$ lower than plasma $\mathrm{T}_{3}$ levels, while in the other tissues these levels are equal to or higher than the levels found in circulation. This could be explained by the relatively high D3 levels in the gills, were it not that in the brain, where D3 activity is at least twofold higher, $\mathrm{T}_{3}$ concentrations are similar to what is present in the plasma. These observations therefore suggest that the gills, in contrast to the other tissues, do not accumulate $T_{3}$; rather, they function as a thyroid hormone metabolizing relay station that is probably involved in regulating plasma $T_{3}$ availability. This hypothesis is supported by the observation that in the $\mathrm{T}_{3}$-supplemented fish, gill $\mathrm{D} 3$ activity reaches maximum levels at the same time that intracellular gill $\mathrm{T}_{3}$ levels do.

The $\mathrm{T}_{3}$-induced hyperthyroidism affected neither hepatic nor renal D1 activity, confirming previous data in fish (Mol et al. 1999, Plohman et al. 2002). In addition, García-G et al. (2004) demonstrated in killifish that, although acute hyperthyroidism did not affect hepatic D1 activity, it readily decreased D1 mRNA expression levels in this tissue. This is in contrast to mammals, where hyperthyroidism stimulates both D1 activity and mRNA expression (Berry et al. 1990). These data indicate that in the substrate-induced regulation of D1 in the liver and kidney, the mechanisms at work in mammals do not seem to apply to fish. This hypothesis is further supported by the observation that in hypothyroid tilapia, hepatic D1 activity, as well as D1 mRNA expression, is upregulated (Van der Geyten et al. 2001), again in contrast to what is observed in mammals (Berry et al. 1990). In contrast, the decrease in D2 activity, as well as the increase in D3 activity, in the liver of $\mathrm{T}_{3}$-supplemented fish conforms more to what is observed in respectively the mammalian brain and liver (Kaplan \& Yaskoski 1980, St Germain 1988, Tu et al. 1999). After withdrawal of the $\mathrm{T}_{3^{-}}$ supplemented food, hepatic D2 and D3 levels gradually return to control values, in concordance with the normalizing plasma $\mathrm{T}_{3}$ levels. Although the liver is considered to be the main source of circulating $\mathrm{T}_{3}$, these changes in hepatic deiodination do not explain how plasma and tissue $\mathrm{T}_{3}$ levels can drop so low so quickly, once the exogenous source of $\mathrm{T}_{3}$ has been removed. In order for this to happen, a fast and efficient mechanism for clearing the excess $T_{3}$ would be required. This could be achieved by stimulating thyroid hormone sulfation and/or glucuronidation, thereby increasing thyroid hormone metabolic clearance rates and hence reducing circulating and tissue $\mathrm{T}_{3}$ levels (Finnson \& Eales 1996, Finnson et al. 1999). Although we did not measure thyroid hormone conjugation in the current study, our finding that exogenously administered $\mathrm{T}_{3}$ resides in the plasma, with a half-life of only $74.37 \pm 4.37 \mathrm{~min}$ (Fig. 9), suggests that tilapia possess a very efficient means of clearing the excess $T_{3}$. This, together with the slowly restoring hepatic $\mathrm{T}_{3}$ production capacity (via D2), may explain why plasma $\mathrm{T}_{3}$ levels drop to only $31 \%$ of control values after removal of dietary $T_{3}$ supplementation.

Previous studies have demonstrated that hyperthyroidism has no effect on D3 activity in the brain and the gills (MacLatchy \& Eales 1993, Morin et al. 1995, Mol et al. 1999, Plohman et al. 2002). In accordance with these data, we also did not observe any effect of $\mathrm{T}_{3}$ supplementation on in vitro brain D3 activity, while gill D3 activity increased together with gill $\mathrm{T}_{3}$ levels. Nor did kidney D3 
react to $T_{3}$ supplementation. Taken together, these data suggest that in the previously published studies $T_{3}$ levels in the gills probably never reached levels high enough to elicit an effect on gill D3 activity. However, this cannot be the case for lack of effect on brain and kidney D3, since the current data demonstrate that, in both these tissues, $T_{3}$ supplementation boosts intracellular $\mathrm{T}_{3}$ concentrations to levels that are equivalent to the levels present in the plasma or the liver. Therefore, we must conclude that $\mathrm{T}_{3}$ regulates D3 activity in brain and kidney differently from D3 activity in liver and gill.

In conclusion, the presented results demonstrate that in hyperthyroid tilapia the increase in plasma $T_{3}$ levels is also reflected in the liver, brain, kidney, gill and white muscle without affecting local $\mathrm{T}_{4}$ concentrations. However, this increase in $T_{3}$ availability remains without effect on D1 activity in liver and kidney. This observation, together with the PTU insensitivity of the D1 enzyme in fish, sets the D1 in teleost fish clearly apart from its mammalian and avian counterparts. The changes in hepatic deiodinases confirm the role of the liver as an important $\mathrm{T}_{3}$-regulating organ. However, the very short plasma half-life of exogenously administered $\mathrm{T}_{3}$ implies the existence of an efficient $\mathrm{T}_{3}$ clearing/degradation mechanism other than deiodination. In addition, fish are remarkably insensitive to exogenous $\mathrm{T}_{4}$ administration via the food. Although this could be partially explained by an inefficient uptake of $T_{4}$ from the gut, our current data suggest that the increased conversion of $\mathrm{T}_{4}$ into $\mathrm{rT}_{3}$ by the $\mathrm{D} 1$ present in the liver also plays an important role in this respect.

\section{Acknowledgements}

We thank W Van Ham, F Voets, L Noterdaeme, T Everaert and E Vanderlinden for their valuable technical assistance.

\section{Funding}

We thank the Rockefeller Foundation for financial support of Dr Nakahazi Byamungu (Biotechnology Career Fellowship RF93029, allocation 208). Serge Van der Geyten was supported by the Fund for Scientific Research - Flanders (Belgium). The authors declare that there is no conflict of interest that would prejudice the impartiality of this scientific work.

\section{References}

Bianco AC, Salvatore D, Gereben B, Berry MJ \& Larsen PR 2002 Biochemistry, cellular and molecular biology, and physiological roles of the iodothyronine selenodeiodinases. Endocrine Reviews 23 38-89.

Berry MJ, Kates AL \& Larsen PR 1990 Thyroid hormone regulates type I deiodinase messenger RNA in rat liver. Molecular Endocrinology 4 743-748.
Byamungu N, Corneille S, Mol K, Darras V \& Kühn ER 1990 Stimulation of thyroid function by several pituitary hormones results in an increase in plasma thyroxine and reverse triiodothyronine in tilapia (Tilapia nilotica). General and Comparative Endocrinology $\mathbf{8 0}$ $33-40$.

Collicutt JM \& Eales JG 1974 Excretion and enterohepatic cycling of ${ }^{125}$ I-L-thyroxine in channel catfish, Ictalurus punctatus Rafinesque. General and Comparative Endocrinology 23 390-402.

Eales JG \& Brown SB 1993 Measurement and regulation of thyroidal status in teleost fish. Reviews in Fish Biology and Fisheries $\mathbf{3}$ 299-347.

Eales JG, Higgs DA, Uin LM, MacLatchy DL, Bres O, McBride JR \& Dosanjh BS 1990 Influence of dietary lipid and carbohydrate levels and chronic 3,5,3'-triiodo-L-thyronine treatment on thyroid function in immature rainbow trout. General and Comparative Endocrinology 80 146-154.

Finnson KW \& Eales JG 1996 Identification of thyroid hormone conjugates produced by isolated hepatocytes and excreted in bile of rainbow trout, Oncorhynchus mykiss. General and Comparative Endocrinology 101 145-154.

Finnson KW \& Eales JG 1999 Effect of $T_{3}$ treatment and food ration on hepatic deiodination and conjugation of thyroid hormones in rainbow trout, Oncorhynchus mykiss. General and Comparative Endocrinology 115 379-386.

Finnson KW, McLeese JM \& Eales JG 1999 Deiodination and deconjugation of thyroid hormone conjugates and type I deiodination in the liver of rainbow trout, Oncorhynchus mykiss. General and Comparative Endocrinology 115 387-397.

García-G C, Jeziorski MC, Valverde-R C \& Orozco A 2004 Effects of iodothyronines on the hepatic outer-ring deiodinating pathway in killifish. General and Comparative Endocrinology 135 201-209.

Higgs DA, Fagerlund UHM, McBride JR \& Eales JG 1979 Influence of orally administered L-thyroxine or 3,5,3'-triiodo-L-thyronine on growth, food consumption, and food conversion of under yearling coho salmon, Oncorhynchus kisutch. Canadian Journal of Zoology $\mathbf{5 7}$ 1974-1979.

Kaplan MM \& Yaskoski KA 1980 Phenolic and tyrosyl ring deiodination of iodothyronines in rat brain homogenates. Journal of Clinical Investigation 66 551-552.

Larsen DA, Dickey JT \& Dickhoff WW 1997 Quantification of salmon alpha- and thyrotropin beta-subunit messenger RNA by an RNase protection assay: regulation by thyroid hormones. General and Comparative Endocrinology 107 98-108.

MacLatchy DL \& Eales JG 1993 Effects of $T_{3}$ and $T_{4}$ challenge on inner and outer ring deiodination of $\mathrm{T}_{3}$ and $\mathrm{T}_{4}$ in the liver, kidney, and gill of rainbow trout, Oncorhynchus mykiss. Journal of Experimental Zoology 265 637-645.

Mol KA, Van der Geyten S, Darras VM, Visser TJ \& Kühn ER 1997 Characterization of iodothyronine outer ring and inner ring deiodinase activities in the blue tilapia, Oreochromis aureus. Endocrinology 138 1787-1793.

Mol KA, Van der Geyten S, Burel C, Kühn ER, Boujard T \& Darras VM 1998 Comparative study of iodothyronine outer ring and inner ring deiodinase activities in five teleostean fishes. Fish Physiology and Biochemistry 18 253-266.

Mol KA, Van der Geyten S, Kühn ER \& Darras VM 1999 Effects of experimental hypo- and hyperthyroidism on iodothyronine deiodinases in Nile tilapia, Oreochromis niloticus. Fish Physiology and Biochemistry 20 201-207.

Morin PP, Hara TJ \& Eales JG $1995 \mathrm{~T}_{4}$ depresses olfactory responses to L-alanine and plasma $T_{3}$ and $T_{4}$ production in smoltifying Atlantic salmon. American Journal of Physiology 269 R1434-R1440.

Moriyama S, Swanson P, Larsen DA, Miwa S, Kawauchi H \& Dickhoff WW 1997 Salmon thyroid-stimulating hormone: isolation, characterization, and development of a radioimmunoassay. General and Comparative Endocrinology 108 457-471. 
Orozco A, Jeziorski MC, Linser PJ, Greenberg RM \& Valverde-R C 2002 Cloning of the gene and complete cDNA encoding a type 2 deiodinase from Fundulus heteroclitus. General and Comparative Endocrinology 128 162-167.

Orozco A, Villalobos P, Jeziorski MC \& Valverde-R C 2003 The liver of Fundulus heteroclitus expresses deiodinase type 1 mRNA. General and Comparative Endocrinology 130 84-91.

Plate EM, Adams BA, Allison WT, Martens G, Hawryshyn CW \& Eales JG 2002 The effects of thyroxine or a GnRH analogue on thyroid hormone deiodination in the olfactory epithelium and retina of rainbow trout, Oncorhynchus mykiss, and sockeye salmon, Oncorhynchus nerka. General and Comparative Endocrinology 127 $59-65$.

Plohman JC, Dick TA \& Eales JG 2002 Thyroid of lake sturgeon, Acipenser fulvescens. II. Deiodination properties, distribution, and effects of diet, growth, and $\mathrm{T}_{3}$ challenge. General and Comparative Endocrinology 125 56-66.

Reyns GE, Janssens KA, Buyse J, Kühn ER \& Darras VM 2002 Changes in thyroid hormone levels in chicken liver during fasting and refeeding. Comparative Biochemistry and Physiology B 132 239-245.

Sanders JP, Van der Geyten S, Kaptein E, Darras VM, Kühn ER, Leonard JL \& Visser TJ 1997 Characterization of a propylthiouracil-insensitive type I iodothyronine deiodinase. Endocrinology 138 5153-5160.

Sanders JP, Van der Geyten S, Kaptein E, Darras VM, Kühn ER, Leonard JL \& Visser TJ 1999 Cloning and characterization of type III iodothyronine deiodinase from the fish Oreochromis niloticus. Endocrinology 140 3666-3673.

St Germain DL 1988 The effects and interactions of substrates, inhibitors, and the cellular thiol-disulfide balance on the regulation of type II iodothyronine $5^{\prime}$-deiodinase. Endocrinology 122 1860-1868.

Sweeting RM \& Eales JG 1992 The acute influence of ingested thyroid hormones on hepatic deiodination pathways in the rainbow trout, Oncorhynchus mykiss. General and Comparative Endocrinology 85 376-384.

Tu HM, Legradi G, Bartha T, Salvatore D, Lechan RM \& Larsen PR 1999 Regional expression of the type 3 iodothyronine deiodinase messenger ribonucleic acid in the rat central nervous system and its regulation by thyroid hormone. Endocrinology 140 784-790.

Valverde-R C, Croteau W, Lafleur GJ Jr, Orozco A \& St Germain DL 1997 Cloning and expression of a 5'-iodothyronine deiodinase from the liver of Fundulus heteroclitus. Endocrinology 138 642-648.

Van der Geyten S, Mol KA, PluymersW, Kühn ER \& Darras VM 1998 Changes in plasma $T_{3}$ during fasting/refeeding in tilapia (Oreochromis niloticus) are mainly regulated through changes in hepatic type II iodothyronine deiodinase. Fish Physiology and Biochemistry 19 135-143.

Van der Geyten S, Toguyeni A, Baroiller JF, Fauconneau B, Fostier A, Sanders JP, Visser TJ, Kühn ER \& Darras VM 2001 Hypothyroidism induces type I iodothyronine deiodinase expression in tilapia liver. General and Comparative Endocrinology 124 333-342.

Received 10 November 2004

Accepted 8 December 2004

Made available online as an Accepted Preprint 10 December 2004 